\title{
Double Perforation after Colorectal Cancer Surgery During Bevacizumab Treatment
}

\author{
Lucian Sorin ANDREI ${ }^{1,2}$, Radu Sorin POPISTEANU' ${ }^{1}$ Adriana ANDREI ${ }^{2,3}$, Alexandru MICU' , Ioana DINU ${ }^{4}$
}

\begin{abstract}
Bevacizumab is a monoclonal antibody which has shown promising results in the treatment of varied malignant pathology, including metastasized colorectal cancer. It acts by inhibiting VEGF (vascular endothelial growth factor), and one of its most cited complications is intestinal perforation, by mechanisms which are not yet fully understood. We present the case of a 68 year old patient, operated for metastasized colorectal cancer, which underwent chemotherapy with Bevacizumab, and shortly after initiating therapy developed fistula of low colorectal anastomosis, followed by ischemic perforation of the small intestine.
\end{abstract}

Keywords: Bevacizumab, metastasized colorectal cancer, ischemic perforation.

\section{Rezumat}

Bevacizumab-ul este un anticorp monoclonal ce a arătat rezultate promițătoare în tratamentul diverselor patologii neoplazice, printre care și cancerul colorectal metastazat. Acesta acționează prin inhibiția VEGF-ului (factor de crestere vascular endotelial), iar una din complicațiile cele mai citate o reprezintă perforațiile intestinale, a cărei mecanism nu este pe deplin elucidat. Prezentăm cazul unui pacient de 68 de ani, operat pentru cancer colorectal metastazat, pentru care a urmat chimioterapie cu Bevacizumab, iar la scurt timp după inițierea terapiei a dezvoltat inițial fistulă de anastomoză colorectală joasă, apoi perforație ischemică de ansă ileală.

Cuvinte cheie: Bevacizumab, cancer colo-rectal metastazat, perforație ischemică.

\section{INTRODUCTION}

Bevacizumab (Avastin) is used in the treatment of metastasized colorectal cancers. Other malignant pathologies in which it is used are renal and pulmonary carcinoma, relapsed glioblastoma and metastasized breast cancer $^{1,2}$. The mechanism by which Bevacizumab acts is the inhibition of VEGF, reducing the process of tumoral angiogenesis ${ }^{3}$. Its most cited side effects are proteinuria, thrombosis/thromboembolism, hypertension and gastrointestinal perforation ${ }^{4,5}$. The incidence of intestinal perforations cited by clinical studies was of about $2 \%$.

\section{CASE PRESENTATION}

We present the case of a 68 year old patient, with history of resected prostate cancer followed by hormone

\footnotetext{
${ }^{1}$ Department of General Surgery, Fundeni Clinical Institute, Bucharest, Romania

${ }^{2}$ Mediproct Clinic, Bucharest, Romania

${ }^{3}$ Department of Gastroenterology, Fundeni Clinical Institute, Bucharest, Romania

${ }^{4}$ Department of Oncology, Fundeni Clinical Institute, Bucharest,

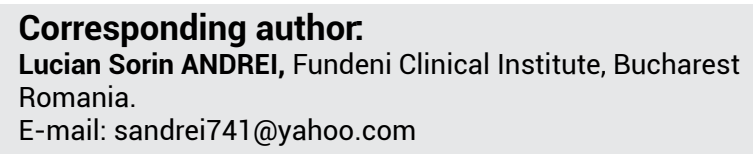


therapy, hepatitis $\mathrm{C}$ related liver cirrhosis (score Child A), diagnosed with rectal cancer at $6 \mathrm{~cm}$ from the anal verge. In January 2016 a colostomy for initiating radiotherapy was performed, and after undergoing neoadjuvant radiotherapy, a low anterior resection with colo-anal anastomosis and diverting loop ileostomy was performed (March 2016). Histological examination of the resected specimen revealed moderately differentiated adenocarcinoma, G2, yRpT3N1b. The patient underwent adjuvant chemotherapy - 6 months of FOLFOX (folinic acid, fluorouracil, oxaliplatin), then had an ileostomy reversal procedure (June 2016). In March 2018, the patient underwent colonoscopy, which detects normal anastomosis at $3 \mathrm{~cm}$ from the anal verge. The follow up CT scan detects bilateral pulmonary metastases. Testing of the paraffin blocks for RAS mutation was performed, which concluded the patient was positive for All-RAS mutation. From March 2018, palliative chemotherapy with CAPOX (capecitabin, oxaliplatin) is initiated, until May 2018, when after multiple hypersensitivity type II reactions to Oxaliplatin, it is changed with CAPIRI (capecitabin, irinotecan). In July and August 2018, two series of Bevacizumab and CAPIRI are administered, with relatively good tolerance. Another follow up CT scan done in August 2018 detects newly developed multiple bilateral lung metastasis. A multidisciplinary team meeting considered the pathology is progressive, and decided on continuing treatment with Bevacizumab and CAPIRI.

In September 2018, the patient is hospitalized with pelvic pain and bowel disorder. CT scan shows anorectal collection, secondary to fistula of low coloanal anastomosis (Figure 1). Biopsies collected at that level exclude tumoral recurrence.
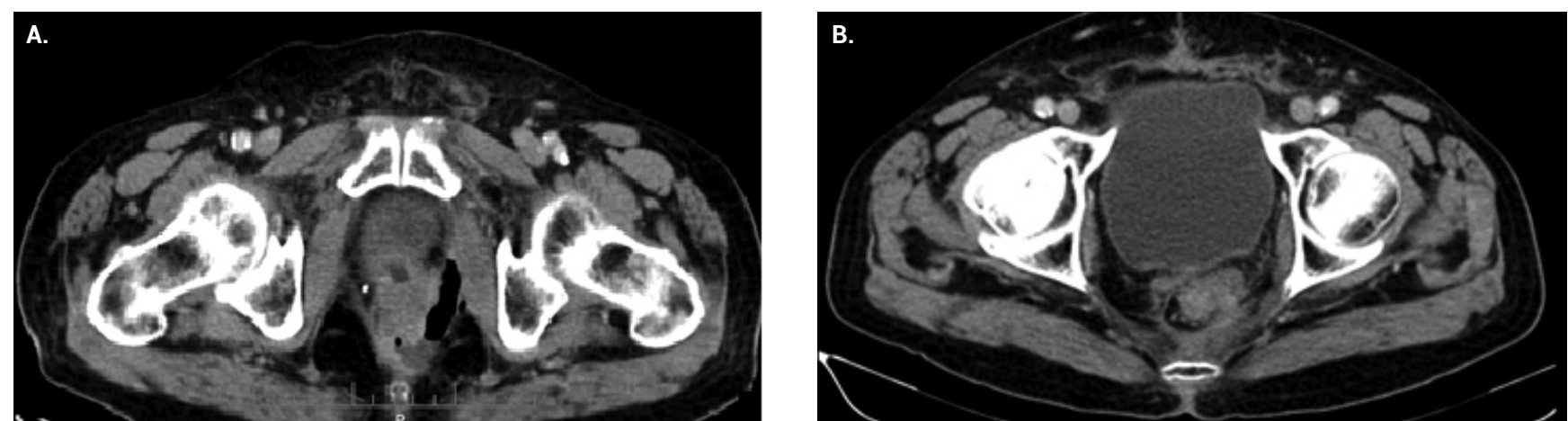

Figure 1. Rectal collection with mixed content (fluid and gaseous), on the left posterior-lateral wall of the rectum, in contact with the left internal obturator muscle, aspect suggesting perianastomotic accumulation secondary to fistula. 


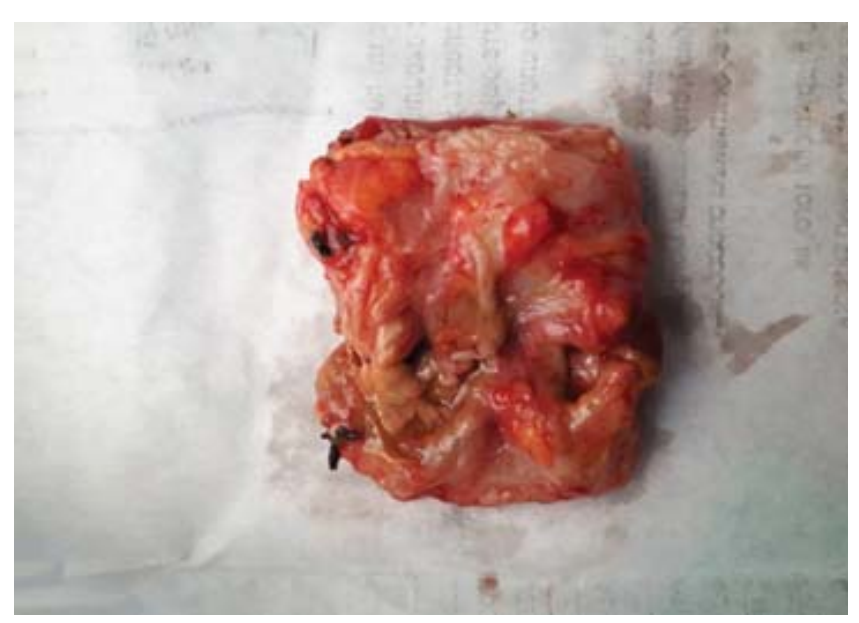

Figure 2. Segmental enterectomy (of aproximately $4 \mathrm{~cm}$ ), with ischemic perforation of about $8 \mathrm{~mm}$.

Another possible mechanism is perforation secondary to tumoral necrosis and regression, due to the lowered permeability and pressure in the interstitial space, which leads to lesions in the intestinal wall and perforation ${ }^{10}$.

Studies have shown a number of factors which raise the risk of intestinal perforation. They are regarding the type of malignant pathology, associated medical history and various therapeutic conducts applied secondary to chemotherapy.

Regarding the types of cancer, most perforations have been reported in cancer of the pancreas, ovary, gastroesophageal, colorectal and renal ${ }^{11}$. Other factors that have been cited in raising the risk of perforation were history of ulcer or diverticulitis, pelvi-abdominal radiotherapy, endoscopies done 1 month prior chemotherapy and the administration of NSAIDs ${ }^{12-14}$.

In our case, the time between initiating chemotherapy and occurrence of the perforation was approximately one month. There is a study in which a patient was operated for ascending colon cancer (colon resection and anastomosis), and underwent chemotherapy with Bevacizumab, Irinotecan and Fluorouracil 8 months after surgery because of newly developed metastasis.
Emergency surgery was required 2 months after chemotherapy for ischemic intestinal perforation ${ }^{15}$. There are also 2 studies published in which intestinal perforation occurred 7 days after chemotherapy ${ }^{16}$.

From the risk factors mentioned before, the patient underwent preoperative radiotherapy and colonoscopy prior to surgical intervention. Another risk factor for both perforations and anastomotic fistula is liver cirrhosis. Patient has history of hepatitis $\mathrm{C}$ related liver cirrhosis score Child A. Regarding anastomotic fistula, a study was conducted on 1875 patients with colorectal anastomosis, of which 24 had liver cirrhosis or severe fibrosis. It was shown that fistula occurrence rate was $12.5 \%$ in patients with cirrhosis, and $2.5 \%$ in those without ${ }^{17}$. Studies have shown that the location of intestinal perforation in patients with cirrhosis is predominantly at the first portion of the duodenum, one study having cited a perforation at the duodeno-jejunal flexure ${ }^{18}$.

\section{CONCLUSIONS}

It has been demonstrated that associating Bevacizumab in the chemotherapy of metastasized colorectal cancer improves survival and response rate ${ }^{19}$. Intestinal perforation is a complication which must be considered after administrating Bevacizumab. The period of time between chemotherapy administration and the occurrence of perforation is variable, and thus early surveillance of signs and symptoms of intestinal perforation is recommended after administering Bevacizumab.

Compliance with ethics requirements: The authors declare no conflict of interest regarding this article. The authors declare that all the procedures and experiments of this study respect the ethical standards in the Helsinki Declaration of 1975, as revised in 2008(5), as well as the national law. Informed consent was obtained from all the patients included in the study. 


\section{References}

1. Sarunas Sliesoraitis, DO, PharmD; Bernard Tawfik, MD-Bevacizumab-Induced Bowel Perforation; The Journal of the American Osteopathic Association, July 2011, Vol. 111, 437-441.

2. Nick Mulcahy-Bevacizumab Significantly Increases GI Perforations - Medscape - May 27, 2009.

3. Jain RK, Tong RT, Munn LL. Effect of vascular normalization by antiangiogenic therapy on interstitial hypertension, peritumor edema, and lymphatic metastasis: insights from a mathematical model. Cancer Res 2007;67:2729-35.

4. Chen HX, Mooney M, Boron M, Vena D, Mosby K, Grochow L, et al. Phase II multicenter trial of bevacizumab plus fluorouracil and leucovorin in patients with advanced refractory colorectal cancer: an NCI Treatment Referral Center Trial TRC-0301. J Clin Oncol 2006;24:3354-60.

5. Richardson DL, Backes FJ, Hurt J, et al. Which factors predict bowel complications in patients with recurrent epithelial ovarian cancer being treated with bevacizumab? Gynecol Oncol. 2010;118(1);47-51.

6. Hurwitz $H$, Fehrenbacher $L$, Novotny $W$, Cartwright $T$, Hainsworth J, Heim W, et al. Bevacizumab plus irinotecan, fluorouracil, and leucovorin for metastatic colorectal cancer. N Engl J Med. 2004;350:2335-2342. PMID: 15175435

7. Young II Choi, M.D.1, Seung Hyun Lee, M.D.1, Byung Kwon Ahn, M.D.1, Sung Uhn Baek, M.D.1, Seun Ja Park, M.D.2, Yang Soo Kim, M.D.2, Seong Hoon Shi, M.D.21Department of Surgery, Kosin University College of Medicine, Busan, Korea. 2Department of Internal Medicine, Kosin University College of Medicine, Busan, Korea; Intestinal Perforation in Colorectal Cancers Treated with Bevacizumab (Avastin $\AA$ )

8. Roodhart JM, Langenberg MH, Witteveen E, Voest EE. The molecular basis of class side effects due to treatment with inhibitors of the VEGF/VEGFR pathway. Curr Clin Pharmacol. 2008;3(2):132-143.

9. Han ES, Monk BJ. What is the risk of bowel perforation associated with bevacizumab therapy in ovarian cancer? Gynecol Oncol. 2007;105(1):3-6

10. Gray J, Murren J, Sharma A, Kelley S, Detterbeck F, Bepler G. Perforated viscus in a patient with non-small cell lung cancer receiving bevacizumab. J Thoracic Oncol 2007;2:571-3.
11. B. D. Badgwell, E. R. Camp, B. Feig, R. A. Wolff, C. Eng, L. M. Ellis, J. N. Cormier, Management of bevacizumab-associated bowel perforation: a case series and review of the literature, Annals of Oncology, Volume 19, Issue 3, March 2008, Pages 577-582

12. Heinzerling $\mathrm{JH}$, Huerta $\mathrm{S}$. Bowel perforation from bevacizumab for the treatment of metastatic colon cancer: incidence, etiology, and management. Curr Surg. 2006;63(5):334-337.

13. Lordick F, Geinitz $H$, Theisen J, et al. Increased risk of ischemic bowel complications during treatment with bevacizumab after pelvic irradiation: report of three cases, Int J Radiat Oncol Biol Phys, 2006, vol. 64 5(pg. 1295-1298)

14. Saif MW, Elfiky A, Salem RR. Gastrointestinal perforation due to bevacizumab in colorectal cancer. Ann Surg Oncol 2007;14:1860-9

15. Abbrederis K, Kremer M, Schuhmacher C, Ischemic anastomotic bowel perforation during treatment with bevacizumab 10 months after surgery.

16. Young II Choi, M.D., Seung Hyun Lee, M.D.,Byung Kwon Ahn, M.D., Sung Uhn Baek, M.D., Seun Ja Park, M.D., Yang Soo Kim, M.D., and Seong Hoon Shin, M.D. Intestinal Perforation in Colorectal Cancers Treated with Bevacizumab; Cancer Res Treat 2008 Mar; 40(1): 33-35.

17. Samuel Andreas Käser, Irina Hofmann, Niels Willi, Felix Stickel, Christoph Andreas Maurer, Liver Cirrhosis/Severe Fibrosis Is a Risk Factor for Anastomotic Leakage after Colorectal Surgery. Hindawi Publishing Corporation Gastroenterology Research and Practice Volume 2016, Article ID 1563037, http:// dx.doi.org/10.1155/2016/1563037

18. Stephanie N. Pilieci, Amir Taheri, Rachel G. Khadaroo; Occult Perforation at the Ligament of Treitz in a Patient with Cirrhosis: A Case Report and Literature Review; SURGICAL INFECTIONS CASE REPORTS Volume 1.1, 2016 Mary Ann Liebert, Inc. Pp. 88-92 DOI: 10.1089/crsi.2016.0021

19. Botrel, T.E.A., Clark, L.G.d.O., Paladini, L. et al. Efficacy and safety of bevacizumab plus chemotherapy compared to chemotherapy alone in previously untreated advanced or metastatic colorectal cancer: a systematic review and meta-analysis. BMC Cancer 16, 677 (2016). https://doi.org/10.1186/s12885-0162734-y. 